\title{
Area Studies
}

Books and Journals from Cambridge University Press

Cambridge has a vibrant programme of books and journals spanning all geographical areas of the world.

We publish prestigious book series and standalone titles that analyse regions through a variety of disciplines in both the humanities and social sciences, ranging from politics, economics and history through to anthropology and religion.

Our multi- and interdisciplinary journals regularly achieve high Impact Factors and lead their respective fields.

For further details visit: cambridge.org/core-areastudies 


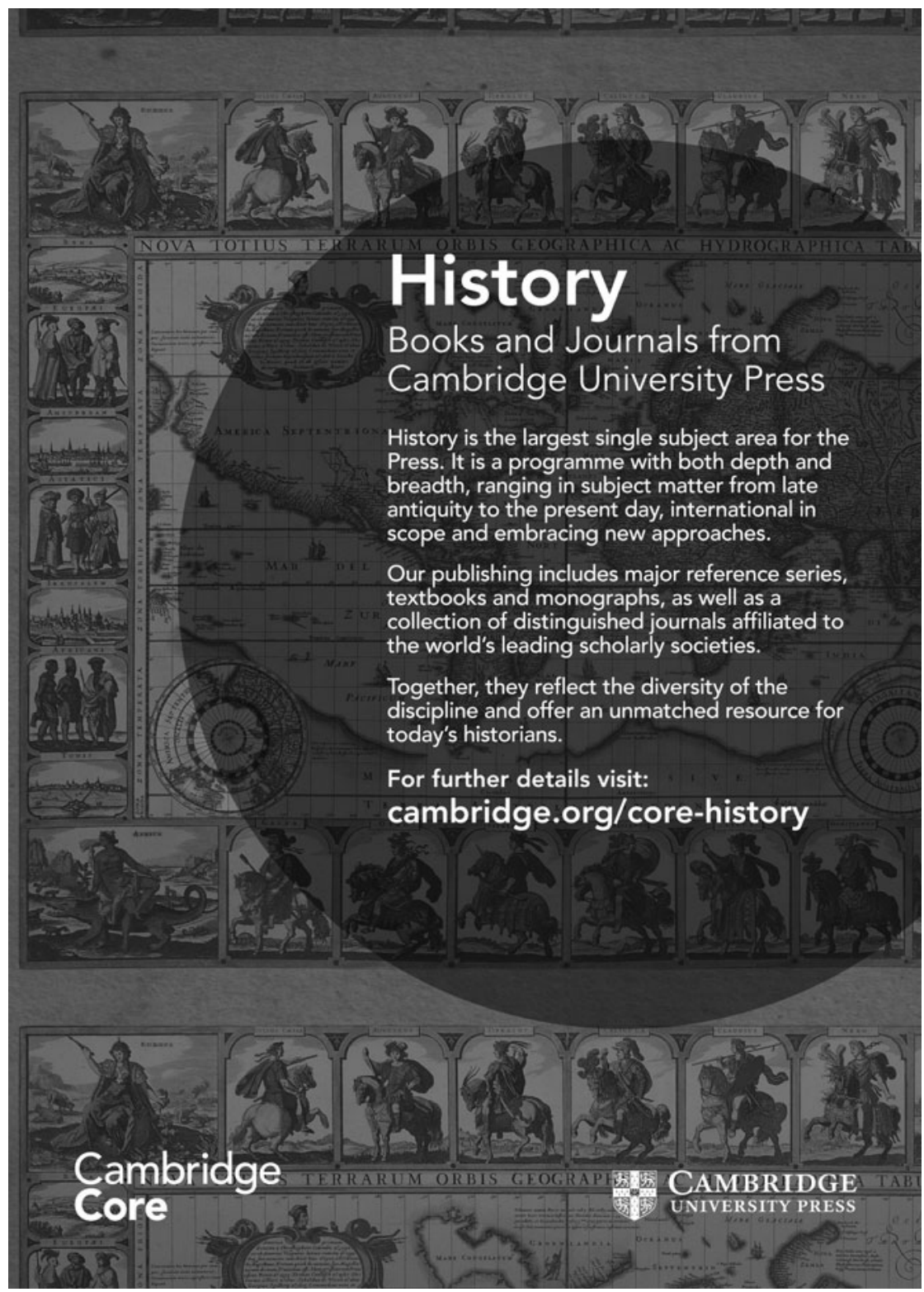




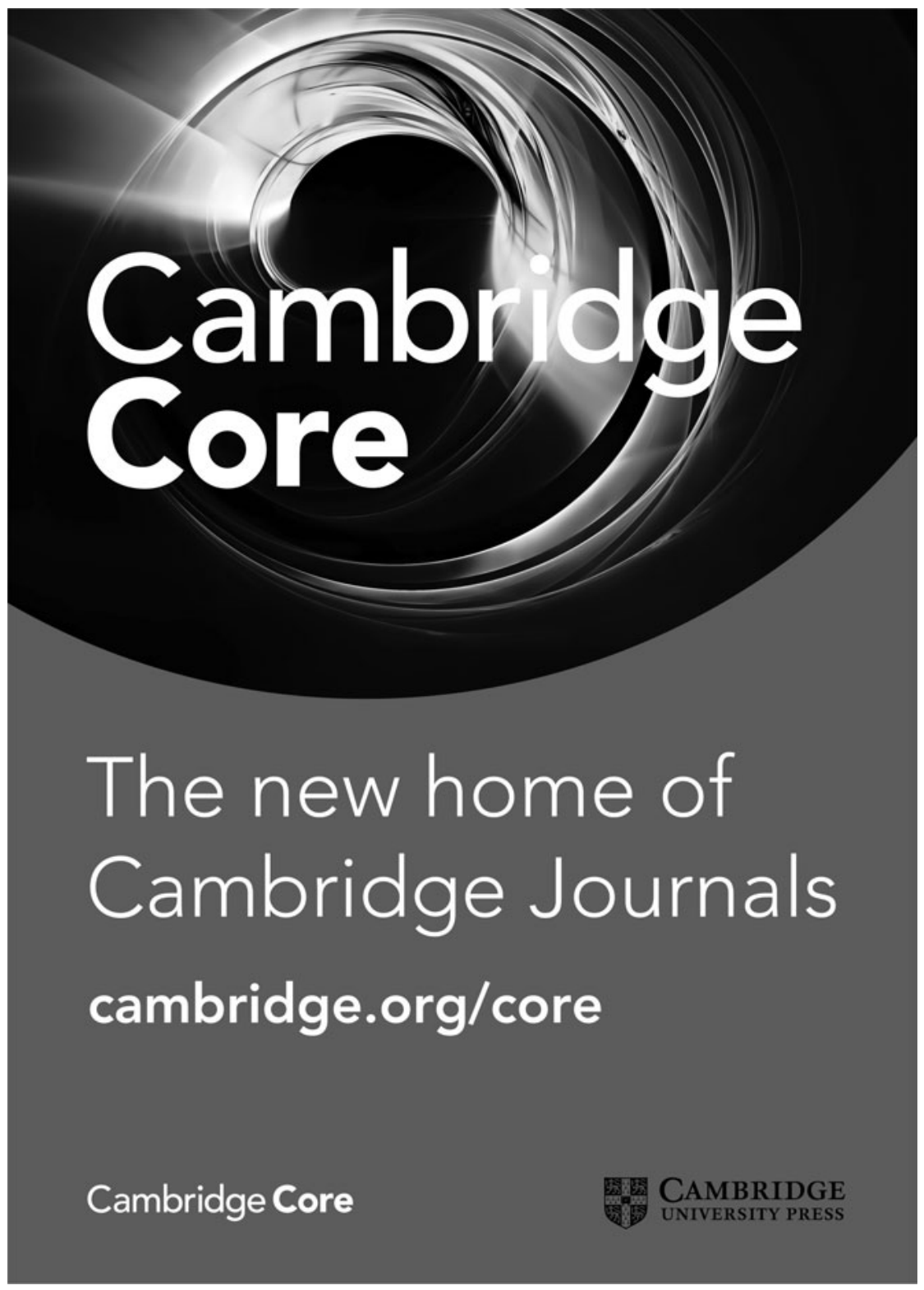


The editors are pleased to receive manuscripts for publication in Africa. For detailed submission instructions, see cambridge.org/afr/ifc.

Manuscripts are considered for publication on the understanding that they have neither been published nor submitted for publication elsewhere. Manuscripts should not exceed 8,000 words (excluding bibliography and notes). Contributors should note that copyright in all articles appearing in the journal is vested in the International African Institute. Contributors will receive twenty offprints and a pdf e-print of their article. Reviewers will receive a pdf e-print of their review.

All correspondence should be sent to The Editors, AFRICA, c/o International African Institute, School of Oriental and African Studies, Thornhaugh Street, Russell Square, London WC1H 0XG, UK.

Editors: africa@internationalafricaninstitute.org

Books for review should be sent to Reviews Editor, AFRICA, Department of International Development, London School of Economics, Connaught House, 6.19. London School of Economics and Political Science, Houghton Street,

London WC2A 2AE.

Book Reviews Editor: bookreviews@internationalafricaninstitute.org

\section{Africa Bibliography}

Africa Bibliography is the authoritative guide to works in African studies, providing a rich and interactive resource for the study of Africa. Published under the auspices of the International African Institute since 1984, the Bibliography is available in print or online on its own or as part of a subscription to Africa. For further details see cambridge.org/afb.

Africa and the Africa Bibliography are publications of the International African Institute, www.internationalafricaninstitute.org.

Africa is published by Cambridge University Press for the International African Institute.

\section{SUBSCRIPTIONS}

Africa (ISSN: 0001-9720) is published quarterly in February, May, August and November by Cambridge University Press for the International African Institute. The four parts form one annual volume. The 2017 subscription price for Africa Volume 87 is $£ 89$ (US\$183) for print and electronic access for individuals. The electronic-only rate is $£ 60$ (US\$116) for individuals. Institutional subscription prices for Volume 87 of Africa include the annual Africa Bibliography and are £565 (U\$1049) for print and electronic access.

The online version of the Africa Bibliography is a fully searchable database and includes multiple years. For further information, visit cambridge.org/afb

All prices include delivery by air if appropriate, and exclude VAT. EU subscribers (outside the UK) who are not registered for VAT should add VAT at their country's rate. VAT registered members should provide their VAT registration number. Japanese prices for institutions (including ASP delivery) are available from Kinokuniya Company Ltd, P.O. Box 55, Chitose, Tokyo 156, Japan.

Orders, which must be accompanied by payment, may be sent to a bookseller, subscription agent or direct to the publisher: Cambridge University Press, Journals Fulfillment Department, University Printing House, Shaftesbury Road, Cambridge CB2 8BS, UK or in the USA, Canada and Mexico: Cambridge University Press, Journals Fulfillment Department, 1 Liberty Plaza, Floor 20, New York, NY 10006, USA. Copies of the journal for subscribers in the USA, Canada and Mexico are sent by air to New York to arrive with minimum delay. Postmaster: send address changes in USA, Canada and Mexico to Africa, Journals Fulfillment Department, 1 Liberty Plaza, Floor 20, New York, NY 10006, USA; or e-mail subscriptions_newyork@cambridge.org

Claims for missing issues will only be considered if made immediately on receipt of the subsequent issue.

\section{COPYING}

This journal is registered with the Copyright Clearance Center, 222 Rosewood Drive, Danvers, MA 01923, USA. Organizations in the USA who are also registered with the C.C.C. may, therefore copy material (beyond the limits permitted by sections 107 and 108 of U.S. Copyright law) subject to payment to the C.C.C of the per copy fee of $\$ 15.00$. This consent does not extend to multiple copying for promotional or commercial purposes. Code 1740-0228/16. ISI Tear Sheet Service, 3501 Market Street, Philadelphia, PA 19104, USA, is authorized to supply single copies of separate articles for private use only. Organizations authorized by the Copyright Licensing Agency may also copy material, subject to the usual conditions. For all other use, permission should be sought from Cambridge or from the American Branch of Cambridge University Press.

Africa is included in the Cambridge Journals Online service which can be found at cambridge.org/afr

Copyright (C) International African Institute 2017

ISSN 0001-9720

E-ISSN 1750-0184

This journal issue has been printed on FSC-certified paper and cover board. FSC is an independent, non-governmental, not-for-profit organization established to promote the responsible management of the world's forests. Please see www.fsc.org for further information. 


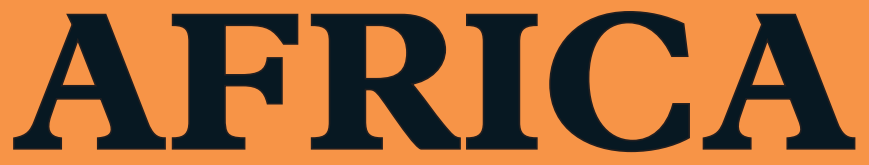

Journal of the International African Institute Revue de l'Institut Africain International

\section{Cambridge Core}

For further information about this journal please go to the journal website at: cambridge.org/afr 